\title{
Evaluation of the safe consumption of aqueous extract of flour from Stichopus variegates
}

\author{
Sherly Ridhowati ${ }^{1, *}$, Ekowati Chasanah ${ }^{2}$, Dahrul Syah ${ }^{3}$, Fransiska R. Zakaria ${ }^{3}$
}

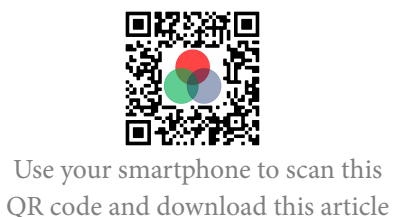

${ }^{1}$ Department of Aquatic Product Technology, Faculty of Agriculture, Sriwijaya University, Indonesia and Graduate student of Bogor Agricultural University, Indonesia

${ }^{2}$ Research and Development Center for Marine and Fishery Product Processing and Biotechnology Center, Jakarta, Indonesia

${ }^{3}$ Department of Food Science, Bogor Agricultural University, Bogor, Indonesia

\section{Correspondence}

Sherly Ridhowati, Department of Aquatic Product Technology, Faculty of Agriculture, Sriwijaya University, Indonesia and Graduate student of Bogor Agricultural University, Indonesia

Email: sherlyridhowati@unsri.ac.id

History

- Received: Aug 05, 2019

- Accepted: Oct 24, 2019

- Published: Nov 27, 2019

DOI : 10.15419/bmrat.v6i11.574

\section{Check for updates}

Copyright

(c) Biomedpress. This is an openaccess article distributed under the terms of the Creative Commons Attribution 4.0 International license.

\begin{abstract}
Introduction: Sea cucumbers of phylum Echinodermata and class Holothuroidea are found on the seafloor worldwide and are widely used in Asian folk medicine. Objective: In this article, our team provide information of the safety consumption as a reference material for the development of functional foods derived from sea cucumber flour. Methods: Stichopus variegatus caught in South Lampung, Indonesia, was processed into flour by vacuum oven, then extracted using hot water to produce Stichopus variegatus-water extract (SV-WE). In the end treatment, the kidney and liver of male $B A L B / C$ mice was analysed using hematoxylin and eosin for a histology data, and blood serum was analysed for biochemical parameters. Results: There was no clinical symptoms in serum biochemistry, histology, and mortality after daily oral administration of SV-WE to male BALB/C mice at 1000,1500 , or 2500 mg/kg body weight/day for 4 weeks. Conclusion: The consumption of SV-WE to male $B A L B / C$ mice was safe, its $L_{50}$ has higher than $2500 \mathrm{mg} / \mathrm{kg} /$ day. Stichopus variegatus sea cucumber flour could be utilized as an ingredient in functional foods.

Key words: Safe consumption, Stichopus variegatus flour, Water extract
\end{abstract}

\section{INTRODUCTION}

Sea cucumbers are marine invertebrates of phylum Echinodermata and class Holothuroidea that are found on the seafloor worldwide ${ }^{1}$. Sea cucumbers are widely used in Asian folk medicine and are traditionally believed to have antibacterial, anti-fungal, anticoagulant, anti-hypertensive, and immune system boosting properties ${ }^{2}$. Scientific investigations have shown that sea cucumbers contain numerous bioactive compounds ${ }^{2}$. Therefore, many researchers, including nutritionists and pharmacologists, have interest to study about the potential of nutraceuticals and functional foods using a sea cucumber ${ }^{3}$.

Despite advances in the pharmacology fields, it is still important to seek alternative therapeutic approaches ${ }^{4}$. There is a strong demand for new medicines that are safe and effective ${ }^{5}$. The marine blue provides a promising source of new therapies, and it has been conjectured that information from traditional medical systems could help to guide the search for useful pharmaceutical agents ${ }^{6}$. In previous time, natural products were commonly used for health maintenance, prevention and treatment of diseases $^{7}$.

Sea cucumber could be a source of functional food. Functional food is effective and safe to use ${ }^{8}$. On the other hand, a report from Sri Lanka mentioned that individuals who consumed sea cucumbers experienced symptoms of vomiting and dizziness ${ }^{9}$. Hashim et al., (2014) reported that the activity of mice was reduced after they were intra-peritoneally administered with a water extract of Holothuria atra ${ }^{10}$. At higher doses, pathological changes were observed in the liver, and the extract had an $\mathrm{LD}_{50}$ of $41 \mathrm{mg} / \mathrm{kg}$. The toxin compounds produced by $H$. atra are watersoluble and are found at higher concentrations in the animal's viscera than in its outer body wall ${ }^{11}$.

In this study, we performed an in vivo evaluation of aqueous extract from sea cucumber flour effect using $B A L B / c$ mice as a model. Wherein sea cucumber flour was made from the species Stichopus variegatus by vacuum oven, which is considered to be an economical replacement for freeze drying. Vacuum oven drying has been used in the industrial-scale processing of raw natural materials into health products, and it can also eliminate the toxic components of sea cucumbers. As known, there is nutritional value degradation from the raw material into flour product ${ }^{12}$. This study provides information about the safety for consumption that may serve as a reference material for the development of functional foods derived from sea cucumber flour. 


\section{METHODS}

\section{Preparation of S. variegatus flour}

Fresh sea cucumbers ( $S$. variegatus) bought alive in South Lampung, Indonesia. S. variegatus flour was made following Ridhowati et al., (2018) methods ${ }^{12}$. Sea cucumber flour was made from $S$. variegatus fresh flesh using vacuum oven with temperature $50^{\circ} \mathrm{C}, 65$ $\mathrm{cmHg}$ for $4 \mathrm{~h}$.

\section{Preparation of Stichopus variegates water extract (SV-WE)}

SV-WE was prepared through the water extraction method published by Farshadpour et al., (2014) with minor modifications. Then, $5 \mathrm{~g}$ flour sample was weighed, then sonicated for 30 mins before the separation was done ${ }^{13}$.

\section{Animals}

Adult male $B A L B / c$ mice weighing up to $20 \mathrm{~g}$ were used throughout this study as male mice are not influenced by hormonal systems. During 7-day adaptation period before the treatment started, each mouse had free accessibility to consume diet and water. The experimental proposal was investigated and approved by the institutional animal ethics committee of Diponegoro University, Central Java, Indonesia, under the registration number No.289/EC/FKM/2014. Animal Research Registry Number: LI2AUJJC (http s://doi.org/10.15419/arr.2019.4)

\section{In vivo study design}

An acute toxicity study as a preliminary assessment was performed before the doses of SV-WE were administered orally to the mice. Acute toxicity assessment of two doses of the extract (low dose, 5 $\mathrm{mg} / \mathrm{kg}$ body weight/day; high dose, $500 \mathrm{mg} / \mathrm{kg}$ body weight/day) was carried out in $10(\mathrm{n}=5$ per group) male $B A L B / c$ mice. The animals showed neither mortality nor signs of toxicity during 7 days of treatment based on the OECD Guideline $423^{14}$.

Twenty-eight age- and weight-matched male $B A L B / c$ mice were randomly divided into a control group (D0, Group 1) and three treatment groups (Groups 2, 3, and 4, which were administered with SV-WE at doses of 1000 (D1), 1500 (D2), and 2500 (D3) mg/kg body weight/day, respectively) ( $n=5$ per group). The assay was performed following the recommendations of OECD Guidelines $423^{14}$. Each SV-WE dose was administered by oral gavage in a volume of $0.5 \mathrm{~mL} / \mathrm{kg}$ body weight once daily for 4 weeks, except the control animals, who were given a distilled water (free salts).
After an oral treatment, observation of all animals was done every $30 \mathrm{~min}$ for $4 \mathrm{~h}$. The animals were observed for general appearance twice daily and body weight, food intake, and water consumption were recorded weekly from the start of the period. These observations were continued for 14 days post-administration for the remaining 28 age-matched $B A L B / c$ mice.

\section{Necropsy}

At the end of the treatment period, all $B A L B / c$ mice were sacrificed by anaesthesia with ketamine. All organs were carefully examined macroscopically, and the liver and kidneys were weighed.

\section{Histology}

An animal tissue was cut using a microtome with a slice thickness of $4 \times 6 \mu \mathrm{m}$. The phosphate-buffered formalin $10 \%$ was used for fixing and preserving the animal organs. For histology, the collected animal tissues were stained using hematoxylin and eosin. The observation of animal tissue was done under a light microscope at 100-1000 x magnification.

\section{Serum biochemistry}

Serum biochemical parameters (total serum protein, aspartate aminotransferase [AST], alanine aminotransferase [ALT], creatinine, blood urea nitrogen, glucose, and total serum lipid) were measured with a Daiichi diagnostic reagent kit and an automated serum analyser (Hitachi 7060 chemistry analyser, Tokyo, Japan) by the commercial laboratory company. Sodium $(\mathrm{Na})$, potassium $(\mathrm{K})$, and chloride $(\mathrm{Cl})$ were measured using an electrolyte analyser (Bayer $644 \mathrm{Na} / \mathrm{K} / \mathrm{Cl}$ analyser, PA, USA) by the commercial laboratory company, when the treatment period finished.

\section{Statistical analysis}

All the data were expressed as mean \pm standard deviation of three replicates. Statistical tests were done using SAS 9.1.3 software (SAS Institute, Cary, NC, USA). Differences with $p$-values of less than 0.05 $(p<0.05)$ were considered to be significant.

\section{RESULTS}

\section{Effects of dietary SV-WE supplementation on body and organ weights in ice}

There was no deaths or abnormal clinical signs related to oral treatments during 4 weeks. Significant increases in body weight, food intake, and liver weight during the treatment period were observed in the mice administered with $2500 \mathrm{mg} \mathrm{SV}-\mathrm{WE} / \mathrm{kg}$, 
relative to those of the control group $(p<0.05)$. In addition, a statistically significant increase in body weight was detected in the $2500 \mathrm{mg} / \mathrm{kg}$-administered group during the post-treatment period, compared with that of the $1500 \mathrm{mg} / \mathrm{kg}$-administered group ( $p<$ 0.05) (Figures 1 and 2).

\section{Serum biochemistry}

Serum biochemical data are summarized in Figure 3 and Figure 4. The groups of mice treated with SV-WE tended to have lower mean serum concentrations of ALT and AST than control mice during the treatment period, and higher serum concentrations during the post-treatment period, with some evidence of a dosedependent response.

In this study, the serum concentration of glucose was significantly altered in experimental groups, compared with that of the control group during both the experimental and post-treatment periods, most consistently in the $1500 \mathrm{mg} / \mathrm{kg}$-administered group $(p<0.05)$. Serum concentration of glucose tended to be increased in treated mice during the treatment period and decreased during the post-treatment period, in comparison with that of the control group (Figure 4).

For total lipids, the average concentration of total lipids in the treated mice was decreased during the treatment period, but increased during the recovery period, compared with the control mice, and differences among groups were detected by the analysis of variance test during both periods $(p<0.05)$. In this study, the average concentration of urea was significantly different between groups during the treatment period $(p<0.05)$, and a trend towards of a dosedependent has decreased between the treated groups to the control group. Based on the data presented in Figure 3, the average concentrations of electrolytes (sodium, potassium, and chloride) did not significantly differ between the control and treated mice during the treatment period ( $p>0.05)$. In contrast, the average concentrations of the electrolytes significantly differed among groups during the post-treatment period $(p<0.05)$ (Figure 4).

\section{Histology}

Histological analysis of the liver was performed at the end of the post-treatment period (Figure 5).

There was no evidence of necrosis among hepatocytes from the control group and the two lower-dose experimental groups (groups D1 and D2), and hepatocyte damage in these groups was confined to fat degeneration, which is considered to be minor. In groups D1 and D2, the recovery of hepatocytes from a state of fat degeneration to abnormal histological status also appeared to be enhanced.

In Figure 6, the histology of kidney during the treatment and post-treatment periods showed that congestion and urinary protein deposits happened during the treatment period. Then, the cells returned to normal conditions after that period. Tubular epithelial cells could recover from a state of urinary deposits (D2 and D3).

\section{DISCUSSION}

Based on Figure 1 and Figure 2, there was no deaths or abnormal clinical signs related to the oral treatments during observation. Body weight change is often the first sign of toxicity. The body weight as an effect of a test substance on this experiment has a significant unsure for the target evaluation ${ }^{15}$, due to the first reaction of human body as a toxification and easy to observe ${ }^{15}$. These were no toxic signs in any of the examined organs and body weight for all animal groups, not only at the end but also post observation (Figures 1 and 2). These changes were transient and not considered to be related to the SV-WE treatment because they showed no apparent dose dependence. Serum biochemistry can be used as an indicator data of toxicological effects. The fluctuations of ALT and AST concentration during the treatment and posttreatment periods (Figures 3 and 4) have indicated that SV-WE may improve liver function through a hepatoprotective or antihepatotoxic activity ${ }^{16}$. The total serum protein significantly changed during the treatment period. This means that there is damage in the hepatocytes in their structure, but not in their function ${ }^{16}$.

Esmat et al., (2013) demonstrated that hepatotoxicity can be detected as an increased activity of conjugated bilirubin, increased concentrations of ALT, AST, ALP, and an increased ratio of AST/ALT in serum, as well as an elevated concentration of liver triacylglycerol ${ }^{17}$. The values of ALT and AST in this research were still in the standard range of normal mice; 17-77 U/L for ALT and 54-298 U/L for AST ${ }^{18}$. At the higher of sea cucumber flour extract doses, AST and ALT levels decreased compared to control mice. It could be an indicator that there was less necrosis cells and membrane damaged on hepatocytes in treated mice than control mice. When necrosis cells occurred, the cell membrane gets damaged. As AST/ALT remains in the cells, there was no increase in AST/ALT concentration in the serum.

The total protein levels in the period of treatment and post-treatment period were in the standard range ${ }^{19}$. 


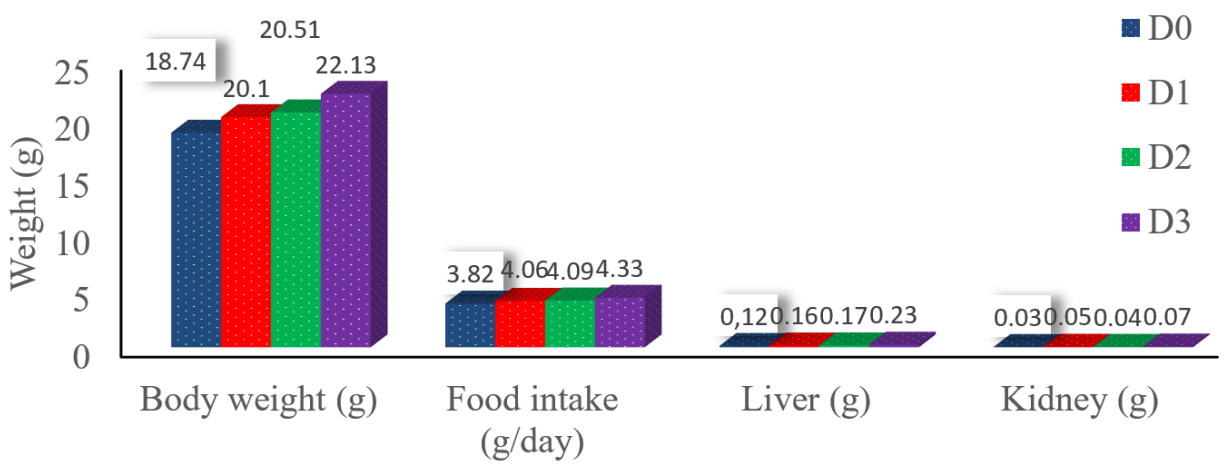

Figure 1: Effects of Stichopus variegatus-water extract (SV-WE) on body weight, food intake, and relative organ weight during the treatment period.

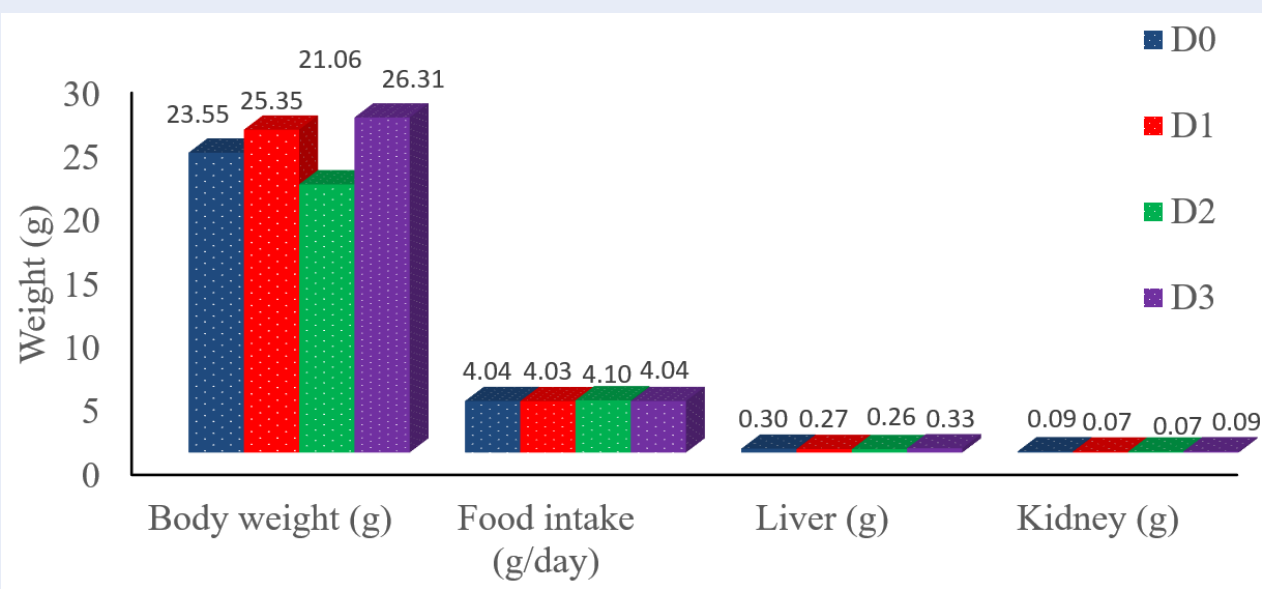

Figure 2: Effects of Stichopus variegatus-water extract (SV-WE) on body weight, food intake, and relative organ weight during the post- treatment period.

Based on Esmat et al. (2013) studied, hepatoxicity can be observed from the increase in marker levels of serum conjugated bilirubin activity, including ALT, AST, ALP, AST/ALT ratio, and liver triacylglycerol concentration $^{17}$.

Blood glucose levels was high and the liver will convert them into fatty acids through lipogenesis, which will be stored in the form of triglycerides in adipose tissues ${ }^{20}$. Based on Figure 3 and Figure 4, glucose levels were decreased in treated mice compared to controls during the treatment and post-treatment periods. However, this concentration was still included in the normal glucose range in mice, which is 62$175 \mathrm{mg} / \mathrm{dL}^{18}$. The SV-WE contain no compounds that could interfere glucose metabolism, especially the function of the pancreas and liver cells in converting glucose into glycogen through glycogenesis reactions. Conversely, the content of sea cucumbers, including free amino acids and peptides, could be antioxidants, which increased the effectiveness of insulin ${ }^{21}$.

In the treatment period, there was a degradation of fat deposits in mice body, and lipids are transported from adipose tissue as free fatty acids (FFA), which are bound to serum protein albumin. Total lipid was increased in post treatment due to the effect of the treatment time.

Total lipid concentration obtained during both periods were still in the normal range for mice, which was equal to $159.25 \mathrm{mg} / \mathrm{dL}^{22}$ and $380 \mathrm{mg} / \mathrm{dL}^{23}$. It showed that SV-WE has impacted to reduce the total lipid in blood serum. Reducing the total lipid could be suspected through two mechanisms, includ- 


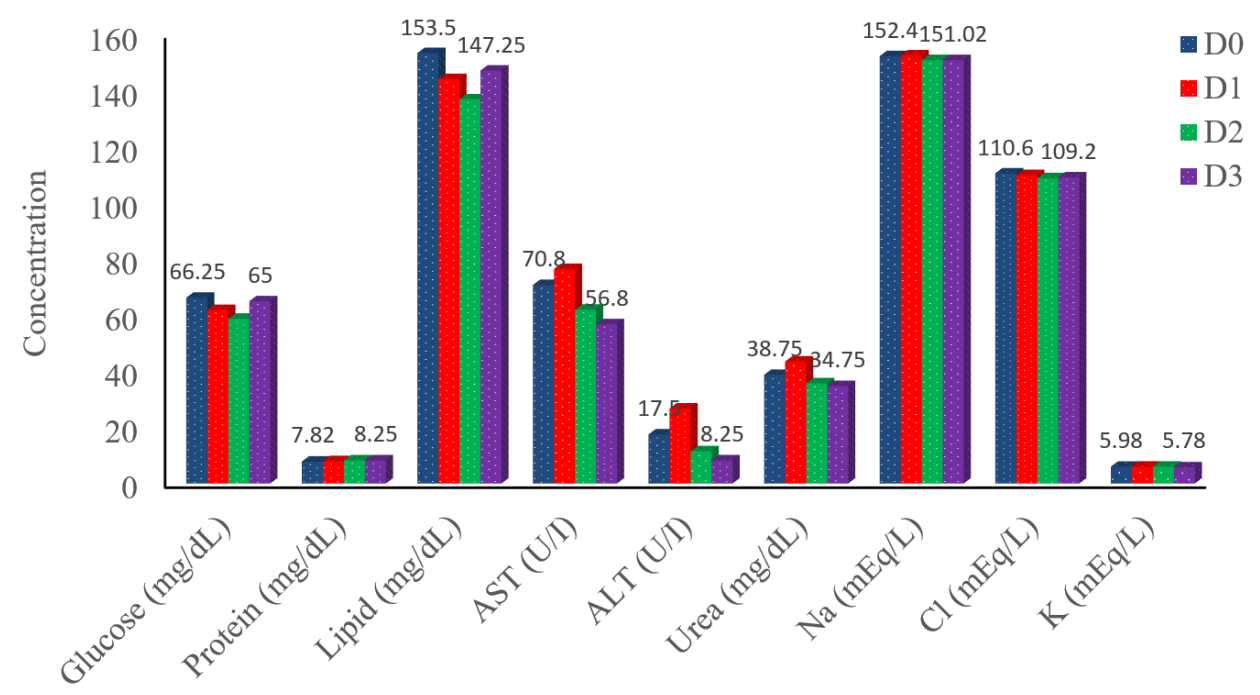

Figure 3: Effects of Stichopus variegatus-water extract (SV-WE) on serum glucose, total protein, total lipid, ALT, AST, urea, natrium, potassium, and chlorine during the treatment period (4 weeks).

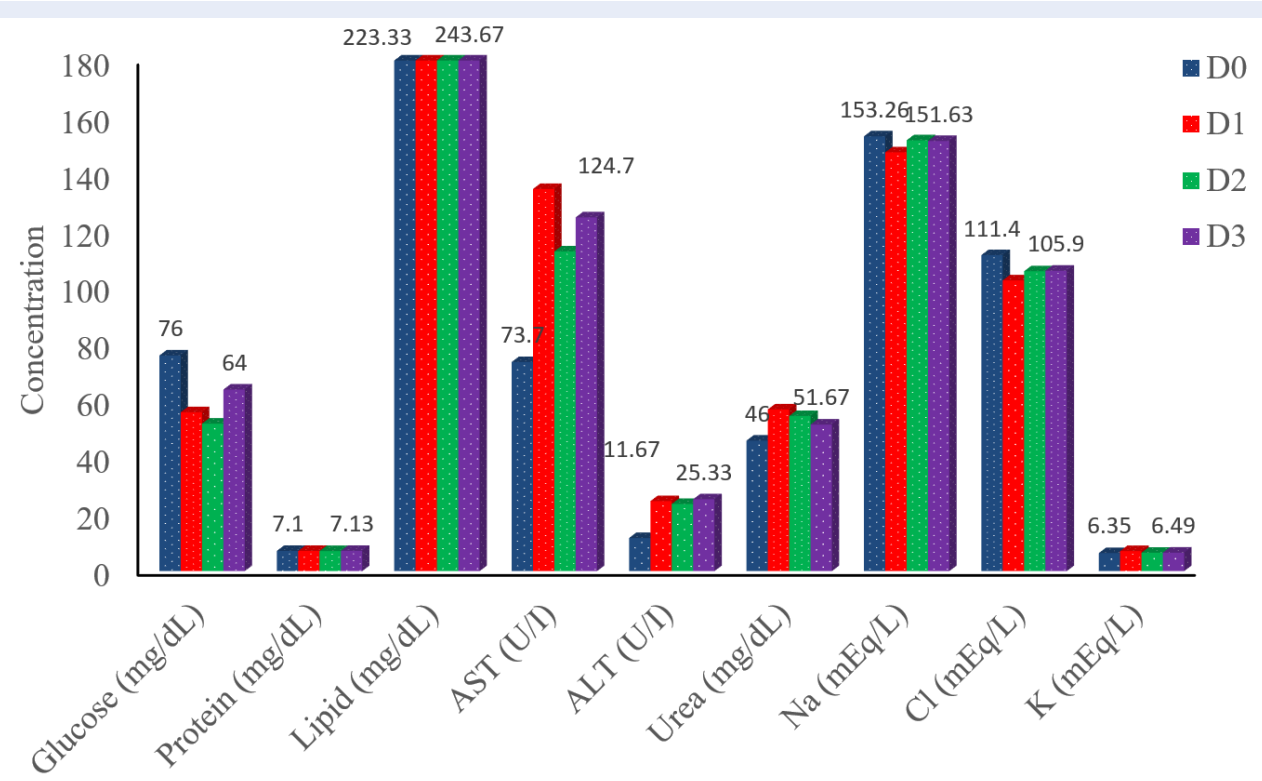

Figure 4: Effects of Stichopus variegatus-water extract (SV-WE) on serum glucose, total protein, total lipid, ALT, AST, urea, natrium, potassium, and chlorine during the post-treatment period (4 weeks). 

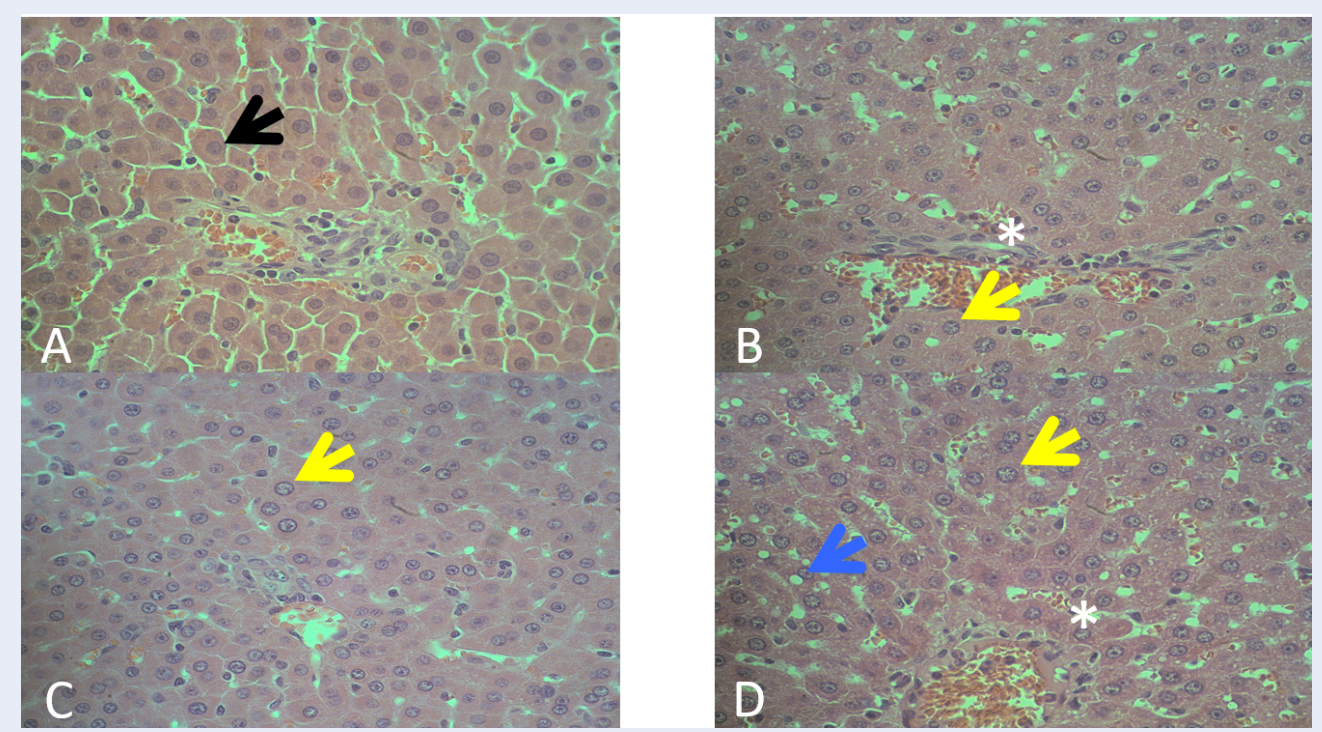

Figure 5: Histology of the liver following 4 weeks of Stichopus variegatus-water extract (SV-WE) treatment and 2 weeks of recovery. (A) The control group showed tubular epithelial cells containing normal nuclei (black arrow). (B) Group D1 showed congestion (blue arrow and asterisks) and urinary protein deposits (yellow arrow). (C) Group D2 showed normal cells. (D) Group D3 showed normal cells and slight urinary protein deposits (yellow arrow). Haematoxylin and eosin staining at $400 \times$ magnification.
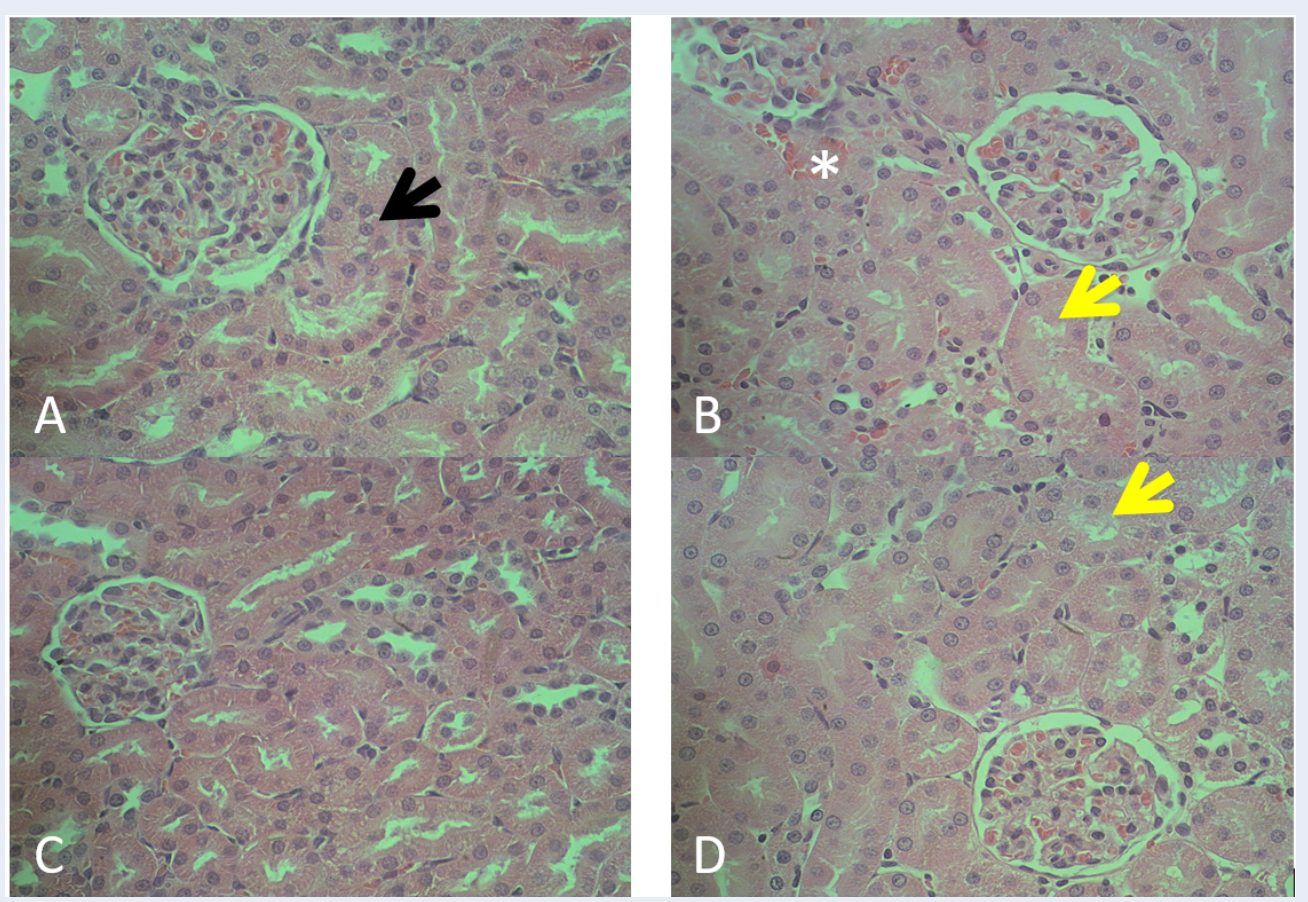

Figure 6: Histology of the kidney following 4 weeks of Stichopus variegatus-water extract (SV-WE) treatment and 2 weeks of recovery. (A) The control group showed tubular epithelial cells containing normal nuclei (black arrow). (B) Group D1 showed congestion (asterisks) and urinary protein deposits (yellow arrow). (C) Group D2 showed normal cells. (D) Group D3 showed normal cells and slight urinary protein deposits (yellow arrow). Hematoxylin and eosin staining at $400 \times$ magnification. 
ing the increase in the rate of $\beta$-oxidation and degradation of the adipose layer. The estimation has supported by blood glucose levels, which also increased through several mechanisms, some energy for activity and metabolism it is also supplied from fat that experiences $\beta$-oxidation.

Based on the data presented in Figure 3 and Figure 4, the urea was increased as the effect of fat and protein accumulation. These results suggested that SV-WE administration enhanced the clearance of urea from serum despite the additional protein input from SVWE. The concentration of urea in serum is affected by the catabolism of amino acids derived from the consumption of proteins and the catabolism of body protein ${ }^{24}$. Plus, it also increased by kidney damage indicators. In the other hands, the measured serum concentrations of glucose, total protein, urea, total lipid, SGPT, SGOT, and electrolytes were in the normal range in all groups ${ }^{18,23,25,26}$. The levels of electrolytes, such as sodium, potassium and chloride between control mice and treatment, were not significantly different during the treatment period (Figure 3). Conversely, the electrolytes were different during the posttreatment period (Figure 4). This means that a kidney effort in maintaining homeostasis. The levels of these electrolytes were still in the normal range, 140-160 $\mathrm{mEq} / \mathrm{L}$ for sodium, $5-7.5 \mathrm{mEq} / \mathrm{L}$ for potassium, and 88-110 mEq/L for chloride ${ }^{18}$. According to Davidson and Henry (1974), the measurement of minerals could be indicators of a kidney failure ${ }^{27}$, including sodium, potassium ${ }^{28}$, and chloride ${ }^{29}$.

Histological observations further revealed that the rapid regeneration of hepatic cells caused by SV-WE administration to the mice resulted in a reduced leakage of ALT, AST, and ALP into the circulation. The results of this study suggested that SV-WE had hepatoprotective effects in mice ${ }^{30}$. The administration of a higher dose of SV-WE to mice (2500 mg SV-WE/kg) caused damage to hepatocytes, leading to the appearance of necrosis Figure 4. Contrarily, at the highest dose, recovery of hepatocytes was also observed more rapidly than at lower doses. It means that the dose of $2500 \mathrm{mg} \mathrm{SV}-\mathrm{WE} / \mathrm{kg}$ was near to the maximum effective dose but was insufficient to induce physiological toxicity.

Based on an analysis of kidney organ histology of the mice at the end of the post-treatment period (Figure 5), all groups showed broadly normal findings. There were no specific lesions as a result of the treatment. In the treatment and post-treatment periods, cell nuclei were normal in all groups, only showed mild congestion and slight urinary protein deposition in the higher-dose treatment groups. These changes were considered to be safe and reversible. Interestingly, hepatocyte repair appeared to be enhanced in the lowest-dose SV-WE treatment group compared to other groups.

\section{CONCLUSIONS}

The sub-chronic oral administration of SV-WE to male $B A L B / c$ mice did not induce clinical signs of toxicity or cause mortality, and its $\mathrm{LD}_{50}$ was higher than $2500 \mathrm{mg} / \mathrm{kg} /$ day. In addition, these findings may increase awareness about the potential SV-WE as an ingredient of a functional food and nutraceuticals.

\section{ABBREVIATIONS}

ALT: Alanine aminotransferase

ALP: Alkaline phosphatase

AST: Aspartate aminotransferase

ASP: Aspartate

LD: Lethal Doses

OECD: Organization for Economic Cooperation and Development

RAR: Research Animal Research

SGPT: Serum glutamic pyruvate transaminase

SGOT: Serum glutamic oxaloacetic transaminase

SV-WE: Stichopus variegatus - water extraction

\section{COMPETING INTERESTS}

There was no competing interests in this research.

\section{AUTHORS' CONTRIBUTIONS}

Envisaged and designed the experiment : Ridhowati, S., Chasanah, E., Syah, D. and Zakaria, F. R.; Extract preparation, animal study, necropsy, histology, and measurement of biochemical parameter: Rihowati, S. and Subangkit, M.; Data analysis: Ridhowati, S.; Manuscript writing : Ridhowati, S.; All authors reviewed, commented and approved the final manuscript.

\section{ACKNOWLEDGMENTS}

The authors would like to express their gratitude to Mawar Subangkit as the attending veterinarian.

\section{REFERENCES}

1. Althunibat OY, Ridzwan BH, Taher M, Jamaludin MD, Ikeda MA, Zali BI. In vitro antioxidant and antiproliferative activities of three Malaysian sea cucumber species. Eur J Sci Res. 2009;(37):376-87.

2. Bordbar S, Anwar F, Saari N. High-value components and bioactives from sea cucumbers for functional foods-a review. Mar Drugs. 2011;9(10):1761-805. PMID: 22072996. Available from: 10.3390/md9101761.

3. Zhong Y, Khan MA, Shahidi F. Compositional characteristics and antioxidant properties of fresh and processed sea cucumber (Cucumaria frondosa). J Agric Food Chem. 2007;55(4):1188-92. PMID: 17243707. Available from: 10. 1021/jf063085h. 
4. Bandgar BP, Gawande SS. Synthesis and biological screening of a combinatorial library of beta-chlorovinyl chalcones as anticancer, anti-inflammatory and antimicrobial agents. Bioorg Med Chem. 2010;18(5):2060-5. PMID: 20138527. Available from: 10.1016/j.bmc.2009.12.077.

5. Soltani M, Parivar K, Baharara J, Kerachian MA, Asili J. Hemolytic and cytotoxic properties of saponin purified from Holothuria leucospilota sea cucumber. Rep Biochem Mol Biol. 2014;p. 43-50. PMID: 26989736.

6. Kong CS, Kim JA, Yoon NY, Kim SK. Induction of apoptosis by phloroglucinol derivative from Ecklonia Cava in MCF-7 human breast cancer cells. Food Chem Toxicol. 2009;47(7):1653-8. PMID: 19393283. Available from: 10.1016/j.fct.2009.04.013

7. Awang K, Azmi MN, Aun LI, Aziz AN, Ibrahim H, Nagoor $\mathrm{NH}$. The apoptotic effect of $1^{\prime}$-S-1'-acetoxychavicol acetate from Alpinia conchigera on human cancer cells. Molecules. 2010;(15):8048-59. PMID: 21063268. Available from: 10.3390/ molecules15118048.

8. Wildman RE. Handbook of nutraceuticals and functional food. Boca Raton: CRC Press; 2011.

9. James DB. Marine Poisonous Echinoderms. Fishing Chimes. 2010;30(1):39-41.

10. Hashim RB, Azizan NA, Zamli Z, Zulkipli FH, Mazlan N, Althunibat OY. Toxicity effects of water extracts of $\mathrm{H}$ olothuria atra Jaeger in mice. Asian Pacific journal of tropical biomedicine. 2014;4(8):614-617.

11. Rao DS, James DB, Girijavallabhan KG, Muthuswamyan S, Najmuddin DM. Biotoxicity in Echinoderms. J Mar Biol Assoc India. 1985;27(1\&2):88-96.

12. Ridhowati S, Zakaria FR, Syah D, E C. Anticancer and Antioxidant activities from sea cucumber (Stichopus variegatus) flour dried vacuum oven. Journal of Tropical Agricultural Science. 2018;41(3):1143-56.

13. Farshadpour F, Gharibi S, Taherzadeh M, Amirinejad R, Taherkhani R, Habibian A. Antiviral activity of Holothuria sp. a sea cucumber against herpes simplex virus type 1 (HSV-1). Eur Rev Med Pharmacol Sci. 2014;18(3):333-7. PMID: 24563431.

14. The Organization for Economic Cooperation and Development. Acute oral toxicity-acute toxic class method. OECD guideline for testing of chemicals No. 423. Paris: OECD; 2001.

15. Sireeratawong $S$, Lertprasertsuke $N$, Srisawat $U$, Thuppia $A$, Ngamjariyawat A, Suwanlikhid N. Acute and subchronic toxicity study of thewater extract from root of Sida rhombifolia Linn. in rats. Songklanakarin J Sci Technol. 2008;30(6):729-37.

16. Qureshi MN, Kuchekar BS, Logade NA, Haleem MA. In-vitro antioxidant and in-vivo hepatoprotective activity of Leucas ciliate leaves. Rec Nat Prod. 2010;(4):1124-30.

17. Esmat AY, Said MM, Soliman AA, El-Masry KS, Badiea EA. Bioactive compounds, antioxidant potential, and hepatoprotective activity of sea cucumber (Holothuria atra) against thioac- etamide intoxication in rats. Nutrition. 2013;29(1):258-67. PMID: 23085016. Available from: 10.1016/j.nut.2012.06.004.

18. Research RA. Animal Research. Reference values for laboratory animals. University of Minnesota Board of Regents. Available from: www.ahc.umn.edu. 2009.

19. Saha S, Ramanathan R, Basu A, Banerjee D, Chakrabarti A. Elevated levels of redox regulators, membrane-bound globin chains, and cytoskeletal protein fragments in hereditary spherocytosis erythrocyte proteome. Eur J Haematol. 2011;87(3):259-66. PMID: 21575061. Available from: 10.1111/ j.1600-0609.2011.01648.x.

20. Murray KR, Graner DK, Mayes PA, Rodwell VW. Harper's ilustrated biochemistry. USA: Mc graw hill companies; 2003.

21. Karnila R. Daya hipoglikemik hidrolisat, konsentrat, dan isolat protein teripang pasir (Holothuria scabra J) pada tikus percobaan [Dissertation]. Bogor: Sekolah Pascasarjana, Institut Pertanian Bogor. 2012

22. Shintawati R., Hernawati, Desi I., Kadar Lipid Darah Mencit Betina MiddleAgedGalur Swiss Webster setelah Pemberian Jus Buah Pare (Momordica charantia L.). Jurusan BiologiFakultas Pendidikan MIPA Universitas Pendidikan. Indonesia MKB. MKB, 2011; 2(43).

23. LaBorde JB, Wall KS, Bolon B, Kumpe TS, Patton R, Zheng Q. Haematology and serum chemistry parameters of the pregnant rat. Lab Anim. 1999;33(3):275-87. PMID: 10780848. Available from: 10.1258/002367799780578156.

24. Kaneko JJ. Clinical biochemistry of domestic animals. New York: Academic Press; 1980.

25. Arbo MD, Schmitt GC, Limberger MF, Charão MF, Moro AM, Ribeiro GL. Subchronic toxicity of Citrus aurantium L. (Rutaceae) extract and p-synephrine in mice. Regul Toxicol Pharmacol. 2009;54(2):114-7. PMID: 19275924. Available from: 10.1016/j.yrtph.2009.03.001.

26. Saha S, Ramanathan R, Basu A, Banerjee D, Chakrabarti A. Elevated levels of redox regulators, membrane-bound globin chains, and cytoskeletal protein fragments in hereditary spherocytosis erythrocyte proteome. Eur J Haematol. 2011;87(3)::259-66. PMID: 21575061. Available from: 10.1111/ j.1600-0609.2011.01648.x.

27. Davidson I, Henry JB. Clinical diagnosis by Laboratory Methods. 15th Edition. Philadelphia: WB Sauber Company. 1974.

28. Osorio FV, Linas SL. Disorders of Potassium Metabolism. 1999. www.kidneyatlas.org.[10 Juni 2014].

29. Taylor PJ, Bouska RA. Automated chloride analysis using the computer. J Anal Methods Chem. 1988;p. 10-4.

30. Hewawasam RP, Jayatilaka KA, Pathirana C, Mudduwa LK. Hepatoprotective effect of Epaltes divaricata extract on carbon tetrachloride induced hepatotoxicity in mice. Indian J Med Res. 2004;120(1):30-4. PMID: 15299229. 